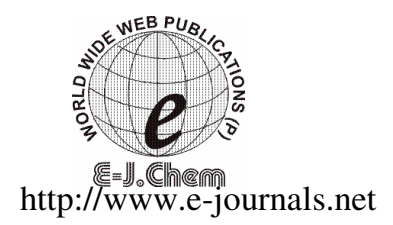

ISSN: 0973-4945; CODEN ECJHAO

E-Journal of Chemistry 2010, 7(S1), S61-S66

\title{
Antibacterial Activity of Quaternary Ammonium Salt from Diethylaminoethyl Methacrylate
}

\author{
MAKHLOUFIA MOHAMMED ${ }^{\S} *$ BENAÏSSA TAHAR ${ }^{\S}$ \\ DERDOUR AÏCHA ${ }^{\#}$ and HENNI DJAMEL EDDINE \\ ${ }^{\S}$ Physical Chemistry Studies Laboratory \\ University of Dr. Moulay Tahar, Saïda - 20000, Algeria \\ \#Applied Organic Chemistry Laboratory, University of Esénia, Oran-31000, Algeria \\ Phytopathology Laboratory, University of Esénia, Oran-31000, Algeria \\ mmakhloufia@yahoo.fr
}

Received 21 January 2010; Accepted 21 March 2010

\begin{abstract}
A quaternary ammonium salt was synthesized from diethylaminoethyl methacrylate (DEAEMA) by quaternization with hexadecyl bromide. The resultant compound (Am-h) was characterized by FTIR and NMR spectroscopy. Its bactericidal activity was evaluated by determining minimum inhibitory concentration (MIC) values and inhibitory zone diameter against gram positive bacteria (Streptococcus $s p$.) and gram negative bacteria such as Acenito baumannii, Klebsiella pneumoniae and Proteus sp. respectively. The results showed that the MIC values of the synthesised compound (Am-h) were $2 . \mu \mathrm{g} / \mathrm{mL}$ against Acenito baumannii, Klebsiella pneumoniae, Proteus sp. and Streptococcus sp.
\end{abstract}

Keywords: Quaternary ammonium salts, DEAEMA, Antibacterial activity, MIC.

\section{Introduction}

Recently, serious infections of microbe have become a social problem ${ }^{1}$. Therefore, safe examination of microbe is very important to human health care at the present time, the most commonly used antimicrobial reagent include cationic active molecules such as quaternary ammonium salts. They attack microorganisms by reacting with specific cellular components or disturbing their metabolism. Their mode of action is selective an independent of $\mathrm{pH}$. The quaternary ammoniums, endowed with anti-microbial properties belong to the family of cationic surfactants ${ }^{2}$. They are used in the hygiene field, made of hydrophobic cationic part 
(the functional of the molecule consisting of nitrogen atom connected to four aliphatic or aromatic groups) and an anion (consisting of either inorganic anion of low molecular weight or an organic anion of high molecular weight) part. These products are stable in acidic and basic medium and are usually soluble in water and alcohols. Their derivatives are bactericidal to a wide variety of bacteria, especially gram positive they often have fungicides, algaecides and virucides properties ${ }^{3}$. Their fields of application are wide; we can cite for example, disinfection of water, surfaces and instruments, antiseptic of healthy skin and injured skin and disinfection of the mucosa, curator of pharmaceutical preparations ${ }^{4}$. There are many other uses such as agriculture, veterinary medicine, cosmology $y^{5}$, food, textile and leather industry. We have prepared the quaternary ammonium salt using a tertiary amine diethylaminoethyl methacrylate (DEAEMA) and halogen derivative of hexadecyl bromide.

\section{Experimental}

DEAEMA (Aldrich, 99\%) posses the following characteristics: B.p. $80{ }^{\circ} \mathrm{C} / 10 \mathrm{~mm} \mathrm{Hg}$, d $0.922 \mathrm{~g} / \mathrm{mL}, 25^{\circ} \mathrm{C}, n_{\mathrm{D}}{ }^{20} 1.444$ and hexadecyl bromide (Aldrich, $97 \%$ ) has the following characteristics: B.p $190{ }^{\circ} \mathrm{C} / 11 \mathrm{~mm} \mathrm{Hg}, \mathrm{d} 0.999 \mathrm{~g} / \mathrm{mL}, 25^{\circ} \mathrm{C}, n_{D}{ }^{20} 1.4609$.

\section{Synthesis of quaternary ammonium salt}

In a $100 \mathrm{~mL}$ flask equipped with a magnetic stirrer, a cooler and a thermometer, $10 \mathrm{~mL}$ of DEAEMA, an expected amount of hexadecyl bromide (hexadecyl bromide / DEAEMA $(1.1 / 1 \mathrm{~mol}))$ and a small amount of hydroquinone were charged. Then 29.2-36.4 mL of acetonitrile was added as solvent. After that, the mixture was stirred with constant interval at 40-45 ${ }^{\circ} \mathrm{C}$. Finally, white needle crystals were obtained by cooling and filtering the reaction solution and then washed with dry ether several times and dried under vacuum at room temperature $^{6}$. The yield of the reaction is about $73 \%$ and the structure of the quaternary ammonium salt (Am-h) obtained is showed in Scheme 1.

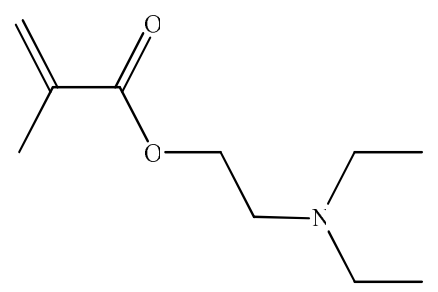

DEAEMA

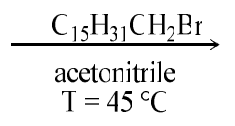

Ammonium salt (Am-h)

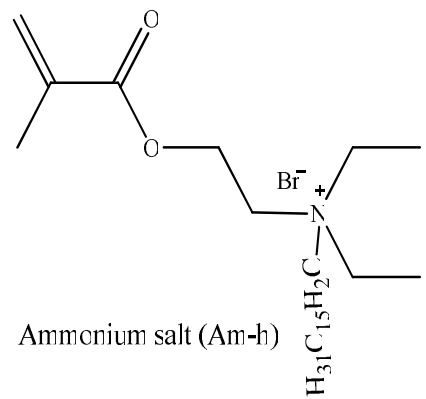

Scheme. 1. Structure of quaternary ammonium salt

\section{Characterizations}

IR spectra of synthesized product was recorded from 400 to $4000 \mathrm{~cm}^{-1}$ on Shimadzu 2401 FTIR spectrophotometer using $\mathrm{KBr}$ pellets with 32 scanning. ${ }^{1} \mathrm{H} \mathrm{NMR}$ and ${ }^{13} \mathrm{C}$ NMR spectra were collected on a FT-NMR (BRUKER-300 MHz) spectrometer using $\mathrm{CDCl}_{3}$ as solvent. The ${ }^{1} \mathrm{H}$ NMR and ${ }^{13} \mathrm{C}$ NMR spectrum of ammonium salt (Am-h) obtained are shown in the Figures 2 and 3 respectively.

\section{Minimum inhibitory concentration (MIC) and the inhibition zone diameter test}

In this work we used the bacteria that have been provided us by the microbiology laboratory of the academic hospital center of Oran (31000) in Algeria. The origin of every strain is shown in the Table 1 . They are descended of the human biologic liquids. The substance was 
received as solid. A starting solution was prepared to a concentration of $0.1 \mathrm{mg} / \mathrm{mL}$ from $0.03 \mathrm{~g}$ of product. Dilutions were done in Eppendorf tubes in the following concentrations: $2,4,8$ and $16 \mu \mathrm{g} / \mathrm{mL}$; this witnessed the solvent used for the solubility of the product. After the preparation of the concentrations, discs made of paper were introduced in every tube and then sterilized to the autoclave to $120^{\circ} \mathrm{C}$ during 20 minutes. After sterilization, the tubes were introduced in the oven so that the solvent evaporates.

Table. 1 Bacterial strains used and origin

\begin{tabular}{ll}
\hline Bacterial strain & Origin \\
\hline Klebsiella pneumoniae & Pus \\
Acinetobacter baumannii & Urine \\
Proteus sp. & Blood culture \\
Streptococcus $s p$. & Endotracheal tube \\
\hline
\end{tabular}

\section{Preparation of the growth medium}

Plates were poured into Petri dishes to a thickness of $4 \mathrm{~mm}$ and left to dry.

\section{Subculture on nutrient agar}

Bacterial strains were inoculated on GN medium. For Streptococcus sp., bacterial strain was inoculated on GN medium; boxes were made in an oven at $37^{\circ} \mathrm{C}$ for $24 \mathrm{~h}$ to obtain a pure culture.

\section{Phase planting}

In the laboratory of the Hospital of Oran, the sensitivity was done by diffusion method. Discs were impregnated with antibacterial solution and measurement of diameter was made using Kirby Bauer method.

\section{Sowing}

Initially, the Petri dishes must contain the MH medium (4mm thick). For Streptococcus sp. using the MH medium supplemented with blood.

\section{Application of the discs}

To test our product, towards the four bacterial strains, we used the discs to the required concentration with a sterilized clip.

\section{Incubation}

For the Streptococcus sp. the incubation was done in a jar at $35{ }^{\circ} \mathrm{C}$ for $24 \mathrm{~h}$. Then we measured inhibitory zone diameters (in millimetre) with a calliper to evaluate the efficiency of our product to test.

\section{Results and Discussion}

\section{Spectral data}

FT IR : $2865-2979 \mathrm{~cm}^{-1}$ (saturated $\mathrm{C}-\mathrm{H}$ stretching vibration), $1720.40 \mathrm{~cm}^{-1}$ (C=O absorption), $1641.30 \mathrm{~cm}^{-1}\left(\mathrm{C}=\mathrm{C}\right.$ stretching vibration), $730 \mathrm{~cm}^{-1}\left(\mathrm{CH}_{2}\right)_{\mathrm{n}} \mathrm{n} \geq 2$ rocking vibration.

(Am-h), ${ }^{1} \mathbf{H}$ NMR $\left(\mathrm{CDCl}_{3}, \delta\right): 6.10(1 \mathrm{H}, \mathrm{a}), 5.64(1 \mathrm{H}, \mathrm{b}), 1.92(3 \mathrm{H}, \mathrm{c}), 4.65(2 \mathrm{H}, \mathrm{d}), 3.95(2 \mathrm{H}$, e), $3.63(2 \mathrm{H}, \mathrm{f}), 3.37(2 \mathrm{H}, \mathrm{g}), 1.83(2 \mathrm{H}, \mathrm{h}), 0.83-1.44(35 \mathrm{H}, \mathrm{j}-\mathrm{k})^{7}$. The yield of the synthesized product was $70 \%$.

(Am-h), ${ }^{13} \mathrm{C}$ NMR $\left(\mathrm{CDCl}_{3}, \delta\right): 127.25$ (C, 1), 135.16 (C, 2), 18.20 (C, 3), 166.43 (C, 4), 57.89 (C, 5), 59.02 (C, 6), 55.02 (C, 7), 8.30 (C, 8), 56.65 (C, 9), 22.63 (C, 10), 26.43 $33.96(\mathrm{C}, 11-\mathrm{C}, 12)^{7}$. 


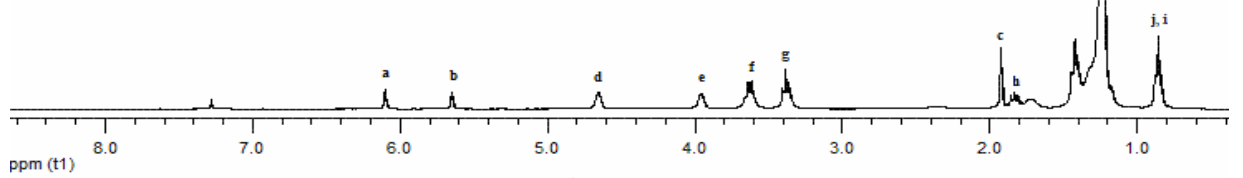

Figure 2. ${ }^{1} \mathrm{H}$ NMR spectra of (Am-h)

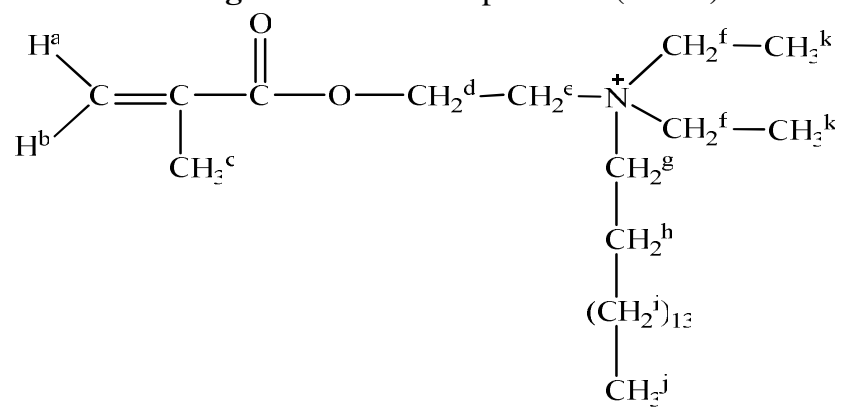

Scheme 2. Structure of quaternary ammonium salt (Am-h)

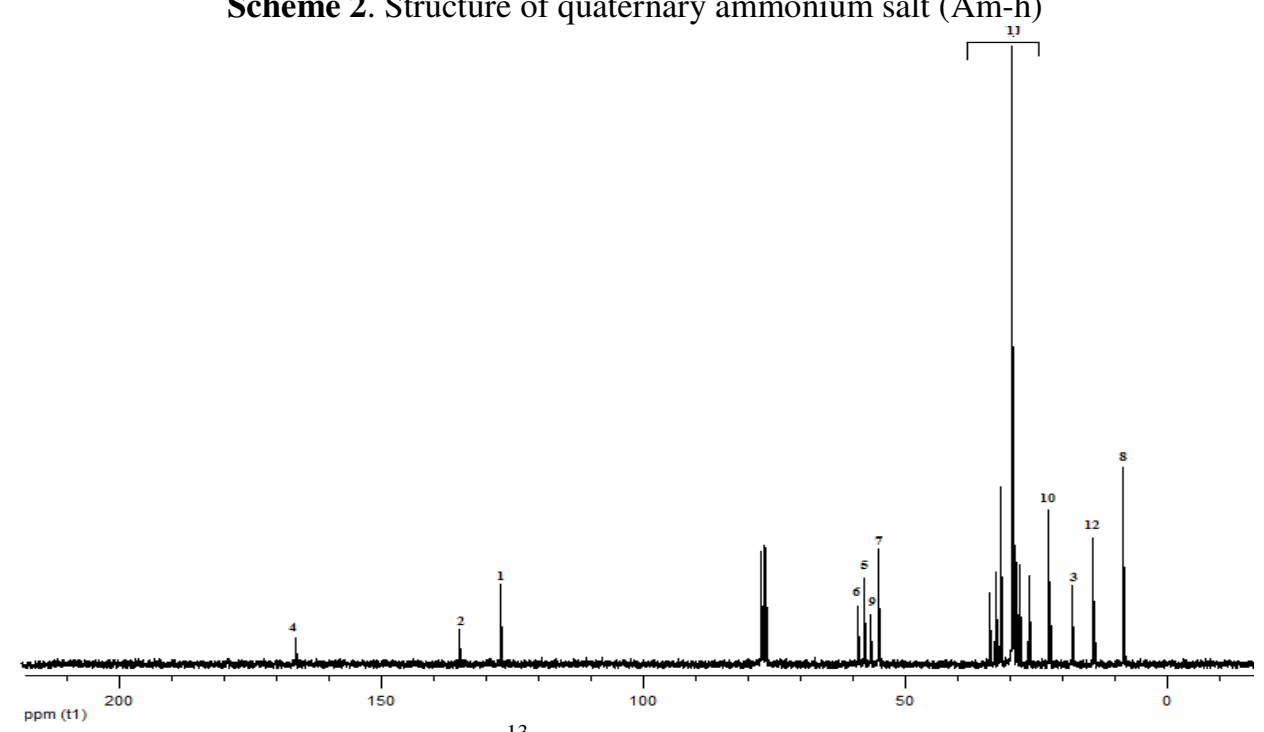

Figure 3. ${ }^{13} \mathrm{C}$ NMR spectra of (Am-h) 


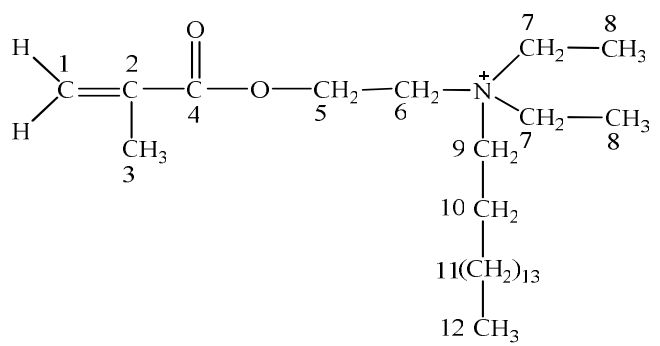

Scheme 3. N,N-diethyl-N-(2-(methacryloyloxy)ethyl)hexadecan-1-aminium

According to the spectroscopic data, we propose the structure of the ammonium salt in the Scheme 1. After having passed the stage of the purification of the bacterial strain and their conservation for a possible use; the Mueller-Hinton medium has been prepared for the test of the bacterial strains sensitivity. The used method was made by test disc paper, $0.1 \mathrm{mg} / \mathrm{mL}$ of the dilute substance. The results of the bacteria sensitivity are presented in the Table 2 .

Table 2. Evaluation of the minimum inhibitory concentration (MIC) and the inhibition zone diameter of (Am-h) compound against the bacteria (Klebsiella pneumoniae, Proteus sp., Acinetobacter baumannii, Streptococcus sp.).

\begin{tabular}{ccccccccc}
\hline Bacteria & \multicolumn{2}{c}{$\begin{array}{c}\text { Klebsiella } \\
\text { pneumoniae }\end{array}$} & Proteus sp. & \multicolumn{2}{c}{$\begin{array}{c}\text { Acinetobacter } \\
\text { baumannii }\end{array}$} & $\begin{array}{c}\text { Streptococcus } \\
\text { sp. }\end{array}$ \\
\hline & MIC & Diam & MIC & Diam & MIC & Diam & MIC & Diam \\
\hline Am-h & $2 \mu \mathrm{g} / \mathrm{mL}$ & $7 \mathrm{~mm}$ & $2 \mu \mathrm{g} / \mathrm{mL}$ & $6 \mathrm{~mm}$ & $2 \mu \mathrm{g} / \mathrm{mL}$ & $6 \mathrm{~mm}$ & $2 \mu \mathrm{g} / \mathrm{mL}$ & $7 \mathrm{~mm}$ \\
\hline
\end{tabular}

The chemical substances synthesized in our laboratory, has been tested to enhance its antibacterial power against gram negative bacteria (Klebsiella pneumoniae, Proteus sp., Acinetobacter baumannii) and gram positive bacteria (Streptococcus sp.). The detection of the sensitivity of these pathogenic bacteria against the tested molecule is made by the realization of an antibiogram. The results show that the product (Am-h) was more efficient for the inhibition of all the bacteria tested. In previous studies the treatment of the bacteria E. Coli and S. aureus by the dimethylaminoethyl methacrylate (DMAEMA) quaternized by hexadecyl bromide showed that the resulting ammonium salt possessed a minimum bactericidal concentration (MBC) values of $12 \mu \mathrm{g} / \mathrm{mL}$ and inhibitory zone diameters of 13.4 and $14.5 \mathrm{~mm}$ respectively ${ }^{6}$.

The high affinity of cationic agents for the membrane suggests a strong interaction with the negatively charged polar head group of phospholipids, an affinity moderated by alkyl chain length in quaternary ammonium salts ${ }^{8}$. Changes in phospholipids packing and phase separation arise from electrostatic interactions ${ }^{9}$. For the quaternary ammonium salts a successive interplay of polar and hydrophobic interactions with the membrane may determine the progress of antibacterial events ${ }^{10}$.

\section{Acknowledgements}

We are grateful to Prof. Henni Djamel Eddine for providing the bacterial strains from Oran Hospital in Algeria.

\section{References}

1. Chapman J S, Int Biodeterior Biodegr., 2003, 51, 133-138.

2. Massi L, Guittard F, Géribaldi S, Levy R and Duccini Y, Int J Antimicrob Agents, 2003, 21, 20-26. 
3. Cationic surfactants: analytical and biological evaluation; Edited by John Cross, Edward J. Singer, Vol.053, Marcel Dekker, 1994.

4. Dauphin A and Mazin C, Les antiseptiques et les désinfectants. Pharmascopie. Soins et thérapies. Paris, Arnette, 1994, 46-47.

5. Feinland R, Pohl S and Hnatchenko M, US Patent, 4,532, 127, 1985.

6. Guiqian. Lu, Dingcai $\mathrm{Wu}$ and Ruowen $\mathrm{Fu}$, Reactive and Functional Polymers, 2007, 67, 355-366.

7. Georg Thieme Verlag, Spectroscopic methods for organic chemistry, Rüdigerstrasse 14, D-70469 Stuttgart, 1995.

8. $\quad$ Brown M R W and Tomlinson E, J Pharm Sci., 1979, 68, 146-149.

9. Broxton P, Woodcock P M and Gilbert P, J Appl Bacteriol., 1984, 57, 115-124.

10. Kopecka Leitmanova A, Devinsky F, Mlynarcik D and Lacko I, Drug Metab Drug Interact., 1989, 7, 29-51. 


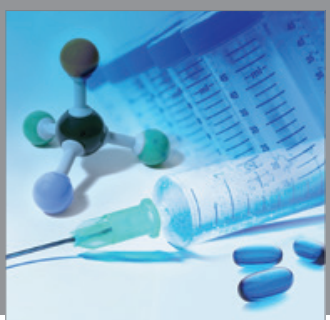

International Journal of

Medicinal Chemistry

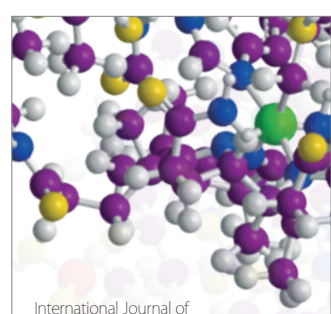

Carbohydrate Chemistry

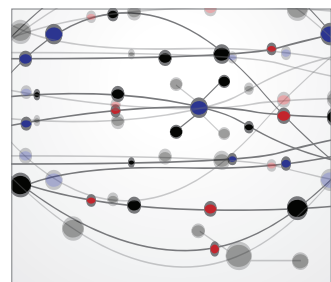

The Scientific World Journal
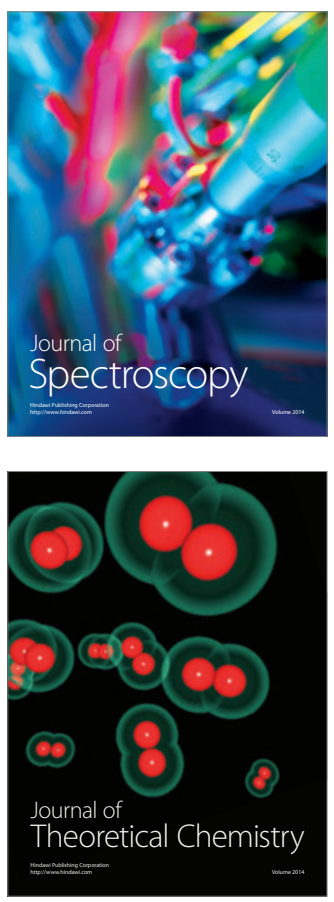
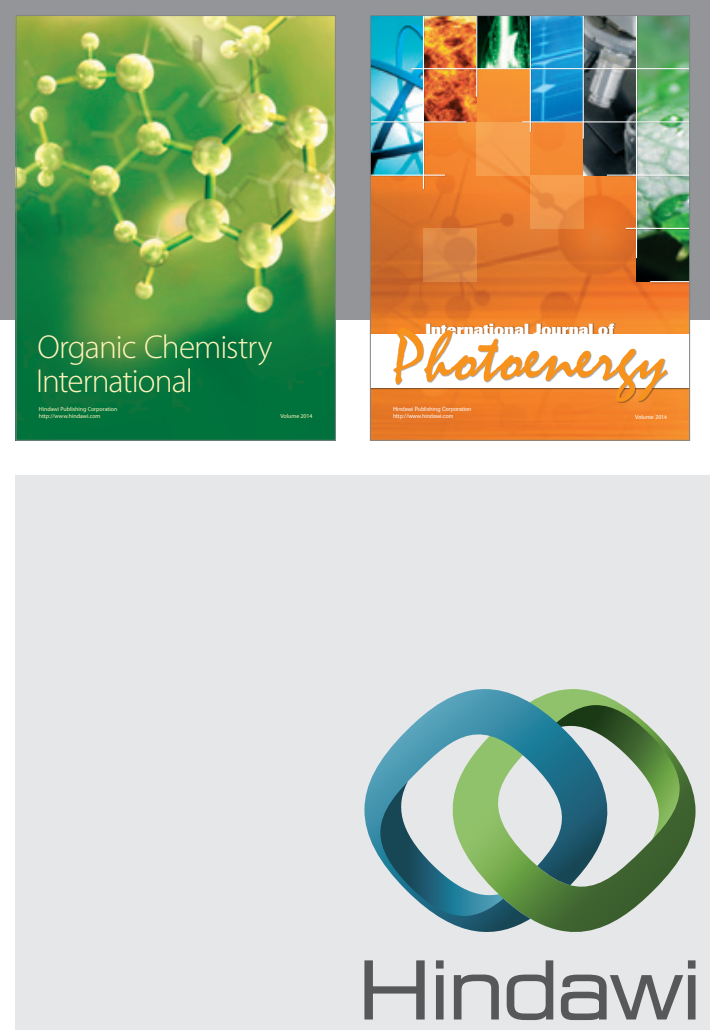

Submit your manuscripts at

http://www.hindawi.com
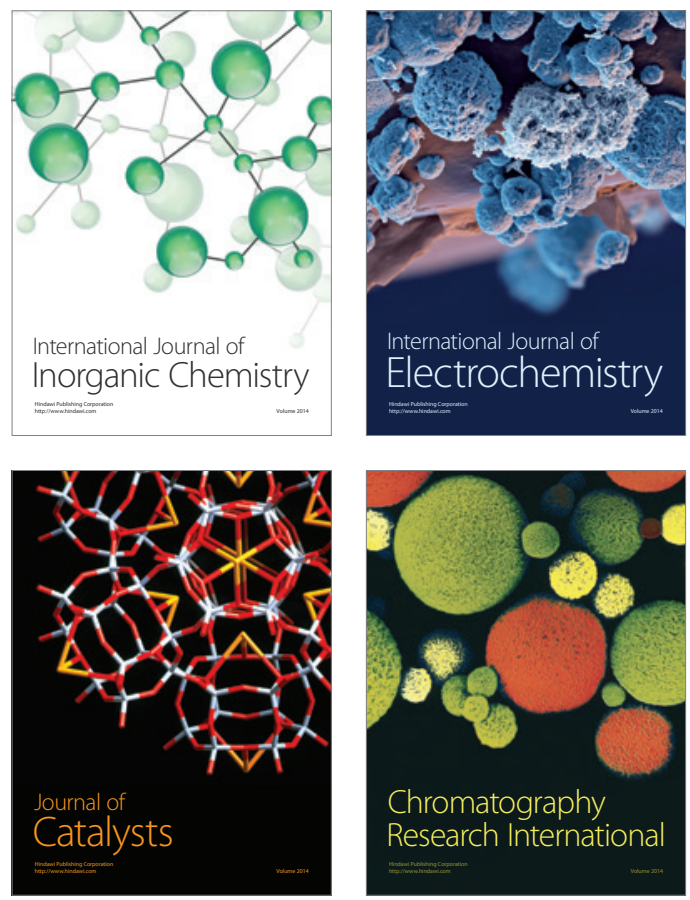
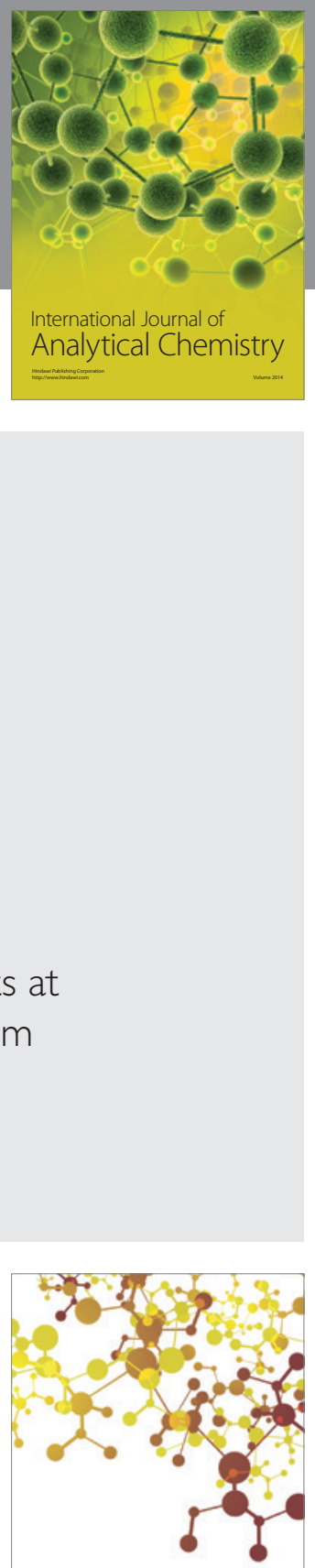

Journal of

Applied Chemistry
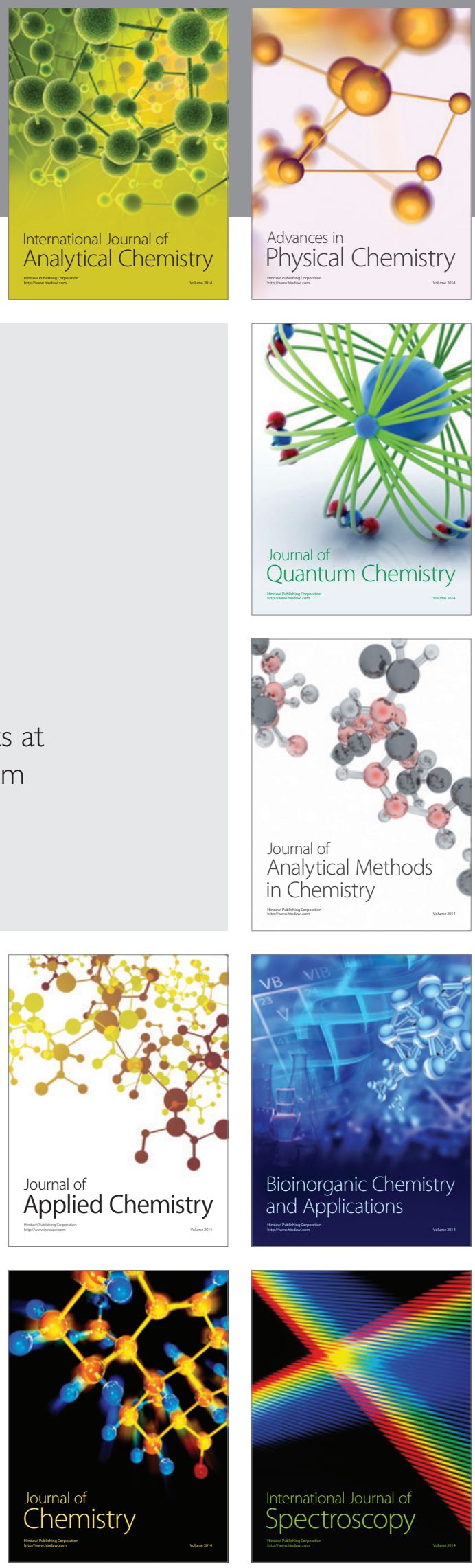